\section{STUDI DESKRIPTIF - EVALUATIF BENTUK TIPOLOGI KAWASAN (PEMBELAJARAN DARI KOTA SURABAYA)}

\author{
R Dimas Widya Putra ${ }^{1 *}$, RM. Petrus Natalivan Indradjati ${ }^{2}$ \\ ${ }^{1}$ Sekolah Arsitektur, Perencanaan dan Pengembangan \\ Kebijakan (SAPPK), Institut Teknologi Bandung, Indonesia \\ ${ }^{2}$ Kelompok Keahlian Perencanaan dan Perancangan Kota, \\ Sekolah Arsitektur, Perencanaan dan Pengembangan \\ Kebijakan (SAPPK), Institut Teknologi Bandung, Indonesia
}

Jurnal Pengembangan Kota (2021)

Volume 9 No. 2 (124-142)

Tersedia online di:

http://ejournal2.undip.ac.id/index.php/jpk DOI: 10.14710/jpk.9.2.124-142

\begin{abstract}
Abstrak. Kota berkembang secara dinamis, fenomena transformasi kota dipengaruhi oleh faktor yang tidak mungkin dihindari, antara lain urbanisasi, perluasan skala pelayanan dan pertumbuhan ekonomi. Adanya urbanisasi dan fungsi pelayanan menjadi penyebab munculnya berbagai jenis tipologi pembangunan kawasan di kota, antara lain: perkampungan, kawasan urban fringe, CBD dan kota baru. Kota Surabaya merupakan kota dengan berbagai bentuk tipologi kawasan, karena itu fenomena bentuk tipologi yang ada di Kota Surabaya menjadi sesuatu yang penting untuk diteliti. Penelitian ini bertujuan untuk mengevaluasi berbagai tipologi pembangunan di Surabaya. Penelitian ini merupakan penelitian deskriptif evaluatif yang dilanjutkan dengan teknik kualitatif. Analisis yang digunakan dalam penelitian ini adalah pembacaan karakter yang di evaluasi berdasarkan pemahaman teori. Hasil dari penelitian ini menunjukkan bahwa Kota Surabaya memiliki beberapa bentuk tipologi pembangunan kawasan, yaitu: CBD, kota baru dan kampung, urban fringe. Penyebab munculnya berbagai bentuk tipologi ini adalah pertumbuhan penduduk, skala pelayanan dan ekonomi.
\end{abstract}

Kata Kunci: Bentuk Tipologi; Kota Surabaya; Transformasi Perkotaan

[Title: Descriptive - Evaluative Study of Typology models (Lesson learned from Surabaya City)]. Cities are developing dynamically, the phenomenon of urban transformation is influenced by factors that cannot be avoided, including urbanization, service scale expansion, and economic growth. Urbanization and service functions transformation cause various urban development typologies, including settlements, urban fringe areas, CBD, and new cities. Surabaya has various development typologies. Therefore the phenomenon of typological forms in Surabaya is something important to be explored. This study aims to evaluate various typologies of development in Surabaya, and This research is an evaluative descriptive followed by a qualitative approach. This research uses character appraisal analysis evaluated based on the theoretical understanding. The result shows that Surabaya has several development typologies, namely: $C B D$, new cities, and kampung, urban fringe area. The causes of the emergence of various typologies of development are population growth, service scale, and economy.

Keywords: Surabaya; Urban Transformation, Urban Typology

Cara Mengutip: Putra, R. Dimas Widya., \& Indradjati, RM Petrus Natalivan. (2021). Studi Deskriptif-Evaluatif Bentuk Tipologi Kawasan (Pembelajaran dari Kota Surabaya). Jurnal Pengembangan Kota. Vol 9 (2): 124-142. DOI: 10.14710/jpk.9.2.124-142

\section{PENDAHULUAN}

Pada keilmuan perencanaan kota, telah dijelaskan bahwa pola pembangunan perkotaan terbagi menjadi beberapa tipe. Menurut Dempsey dkk. (2008) tipe pembangunan perkotaan dapat diklasifikasikan menjadi beberapa, antara lain: tipe pembangunan kompak, tipe pembangunan menyebar, kampung kota, pusat bisnis terpadu dan pembangunan kawasan pinggiran. Klasifikasi tipe pembangunan kota menjadi suatu fenomena yang menarik untuk dikaji, karena kota terbentuk dari karakteristik masyarakat, budaya dan ekonomi. 
Untuk mempelajari tipe pembangunan perkotaan dapat menggunakan teknik pembacaan morfologi kota (Chan dkk., 2011; Chen dkk., 2019; Chen dkk., 2021; Sanders \& Baker, 2016). Teknik pembacaan morfologi perkotaan merupakan metode yang tepat dalam membaca bentuk perkotaan (Sanders, 2013). Variabel bentuk perkotaan sangat beragam, antara lain: ekonomi, distribusi pekerjaan, kepadatan, sirkulasi, tata guna lahan, desain lingkungan, hingga pola pembangunan (AlSaaidy, 2020; Dempsey dkk., 2010; Han dkk., 2020; Sharifi \& Yamagata, 2018; Živković, 2019). Menurut Chen (2014), ilmu morfologi perkotaan merupakan studi tentang bentuk perkotaan yang berfokus pada pembentukan dan transformasi bentuk perkotaan kota, kabupaten, dan desa dari waktu ke waktu. Ilmu morfologi perkotaan juga mempelajari bentuk perkotaan hingga skala spasial.

Moudon (1994) menyatakan bahwa morfologi perkotaan sebagai ilmu pengetahuan yang dikembangkan dari tiga sekolah, antara lain: sekolah morfologi Inggris, sekolah tipologi Italia, dan sekolah versailles Prancis. Masing-masing sekolah ini mengembangkan seperangkat konsep dan pendekatan untuk mempelajari bentuk perkotaan. Diantara tiga sekolah ini, sekolah morfologi Inggris menjadi salah satu yang terkenal. Sekolah morfologi Inggris didirikan oleh ahli geografi Jerman yaitu Michael Robert Günter Conzen (Whitehand dkk., 2009).

Conzen mengembangkan metodologi berharga bagi studi bentuk perkotaan yang terdiri dari tata kota, pola penggunaan lahan, dan bentuk bangunan tiga dimensi. Pendekatan kartografinya, yang didasarkan pada pembacaan peta sejarah, dianggap sebagai pendekatan yang paling berhasil oleh para ahli morfologi untuk menganalisis transformasi perkotaan dari waktu ke waktu. Analisis denah mengevaluasi bagian kota yang terdiri dari plot, jalan, dan blok bangunan yang karakteristiknya digunakan untuk merumuskan rencana kota (Chen, 2014; Han dkk., 2020; Schirmer \& Axhausen, 2016).

Memahami berbagai bentuk tipe pembangunan kawasan kota sangat penting bagi perencana kota, geographer, perancang kota, pegawai badan perencanaan daerah dan ahli bidang keilmuan lainnya untuk dapat memberikan solusi kebijakan terbaik bagi kota dengan mengetahui potensi permasalahan suatu kota dari tipologi nya (Barke, 2018; Ding, 2013; Wei dkk., 2016).

Chen (2014) menyatakan bahwa memahami pembacaan suatu bentuk kawasan yang ada di perkotaan dan morfologi kota dapat bermanfaat bagi bidang manajemen kota, perencanaan dan perancangan kota, konservasi dan regenerasi kota untuk membuat kebijakan perkotaan dalam berkontribusi pada keberlanjutan sosial, ekonomi dan lingkungan. Salah satu fenomena perkotaan dengan berbagai variasi tipologi pembangunan adalah Kota Surabaya. Munculnya berbagai variasi tipe pembangunan di Surabaya juga disebabkan oleh fungsi administratif kota (Fikriyah, 2013; Idawati, 2015; Shirleyana dkk., 2018). Kota Surabaya secara administratif merupakan ibu kota Provinsi Jawa Timur. Fungsi administratif ini menjadikan Surabaya sebagai salah satu pusat perekonomian di Indonesia. Kota Surabaya adalah kota industri yang didukung dengan keberadaan pelabuhan sebagai pusat bongkar muat barang.

Fenomena tersebut menjadikan Kota Surabaya memiliki banyak peluang pekerjaan, sehingga banyak masyarakat melakukan urbanisasi menuju Kota Surabaya untuk bekerja dan bermukim (Indahri, 2017). Proses urbanisasi menuju Kota Surabaya ini tidak hanya dilakukan oleh penduduk dengan keahlian tetapi juga penduduk tanpa keahlian (Zulfiyah, 2017). Pesatnya pertumbuhan penduduk di Kota Surabaya merubah struktur Kota Surabaya karena penduduk dengan berbagai latar belakang ekonomi menjadi satu. Dampaknya, Kota Surabaya berkembang meluas dengan pembangunan baru ke arah pinggiran-pinggiran. Berbagai variasi tipe pembangunan bermunculan di beberapa kawasan, baik kawasan tingkat ekonomi atas hingga ekonomi miskin. Kawasan ini

ISSN 2337-7062 @ 2021

This is an open access article under the CC-BY-NC-ND license (http://creativecommons.org/licenses/by-nc-sa/4.0/). - lihat halaman depan (C) 2021

*Email r.dimasp@yahoo.com

Diterima 21 Desember 2020, disetujui 30 November 2021 
memiliki berbagai karakternya. Berbagai variasi pengembangan di Surabaya antara lain : kampung kota (Damayanti, 2015; Putra, 2017; Santoso, 2017; Setijanti dkk., 2016; Shirleyana dkk., 2018; Silas, 1988; Silas \& Ernawati, 2013) ; kota baru (Fikriyah, 2013; Idawati, 2015; Kwanda, 2000) ; pusat bisnis terpadu (Navastara \& Mandasari, 2019; Sistyaningsih \& Kisnarini, 2017); dan urban fringe (Maharani \& Umilia, 2014; Shirleyana dkk., 2018).

Dari berbagai fenomena dan teori yang muncul, maka tujuan penelitian ini adalah: (1) mengetahui berapa banyak variasi tipe pembangunan kawasan yang ada di Kota Surabaya. (2) mengidentifikasi elemen bentuk kota (tata guna lahan, jalan dan bangunan) yang mempengaruhi terbentuknya beberapa tipe kawasan di Kota Surabaya.

Hasil temuan studi ini terkait cara mengevaluasi elemen kota sebagai pembentuk berbagai tipe pembangunan di Surabaya yang akan membantu perencana dan perancang kota, pemerintah, dan geographer dalam mengevaluasi struktur suatu kota.

\section{METODE PENELITIAN}

Jenis penelitian ini adalah deskriptif - evaluatif dengan pendekatan kualitatif. Penelitian evaluatif adalah penelitian yang sifatnya mengevaluasi suatu program, kegiatan, teori atau temuan dengan tujuan untuk mengukur suatu kegiatan, program dan penelitian melalui kegiatan membandingkan pada temuan teori terdahulu (Chua dkk., 2017; Dharmayana \& Herawati, 2021; Kantun, 2017; Ostad-Ali dkk., 2015; Putra, 2017; Sasongko, 2018).

Deskriptif evaluatif yang digunakan dalam penelitian ini adalah melakukan evaluasi terhadap teori dan temuan penelitian-penelitian terdahulu. Penelitian-penelitian terdahulu ini dicari dengan menggunakan mesin pencarian google pada situs google books, google scholar, ScienceDirect dan sinta web journal.

Pendekatan kualitatif dalam penelitian ini digunakan untuk menafsirkan hasil evaluasi variasi tipe kawasan di Kota Surabaya berdasarkan landasan teori sebagai pemandu agar fokus penelitian sesuai dengan pembacaan kasus studi. Menurut Creswell (2017), penelitian kualitatif memuat informasi tentang fenomena utama yang sedang di eksplorasi dalam suatu penelitian, partisipan penelitian, dan lokasi penelitian. Penelitian kualitatif dimulai di lapangan yang didasarkan pada fakta empiris, bukan teori. Data dan informasi yang diperoleh dari lapangan diambil makna dan konsepnya, disajikan secara deskriptif analitis dan umumnya tanpa menggunakan angka-angka, karena mengutamakan proses-proses yang terjadi di lapangan.

Penelitian ini dilakukan pada tahun 2021 menggunakan hasil survei data-data struktur ruang Kota Surabaya yang dilakukan pada rentang tahun 2020 hingga 2021. Data-data yang digunakan dalam penelitian ini adalah: peta garis dan struktur ruang kota yang meliputi tata guna lahan, persil bangunan, dan bentuk jalan. Datadata ini diperoleh dari GIS badan perencanaan daerah Kota Surabaya, open street map dan peta citra satelit. Semua data ini akan dievaluasi berdasarkan temuan atau teori sebelumnya.

Data-data tata guna lahan, persil bangunan, dan bentuk jalan ditampilkan menggunakan GIS, open street map, Map surfer ASTER GDEM - SRTM hill shade. Hasil tampilan peta ini kemudian di evaluasi menggunakan metode penilaian karakter berdasarkan landasan teori dan temuan penelitian sebelumnya. Hasil evaluasi ini dibaca secara deskriptif terkait jenis pola jalan, penggunaan lahan, pola bangunan dan bahkan sejarah kawasan. Sehingga dari hasil pembacaan ini dapat disimpulkan struktur morfologi pola pengembangan Kota Surabaya.

Alasan dipilihnya Kota Surabaya sebagai kasus studi karena Kota Surabaya memiliki elemen konfigurasi ruang yang bervariasi meliputi tata guna lahan, kepadatan permukiman, ruang terbuka dan kondisi perekonomian yang beragam dan struktur konfigurasi ruang yang lengkap dan beragam, yaitu: adanya tipologi kawasan kota 
baru, kampung kota, pusat bisnis terpadu, kawasan pinggiran untuk kelas pekerja (Damayanti, 2015; Fikriyah, 2013; Idawati, 2015; Kwanda, 2000; Putra \& Pradoto, 2016; Setijanti dkk., 2016; Shirleyana dkk., 2018; Silas \& Ernawati, 2013; Sistyaningsih \& Kisnarini, 2017).

Morfologi atau struktur konfigurasi ruang yang bervariasi dan lengkap ini menjadikan Kota Surabaya menjadi berbeda dibandingkan kota lainnya di Indonesia atau di luar negeri. Variasi morfologi tipe pengembangan kawasan di Surabaya mungkin akan memiliki kemiripan dengan kota metropolitan besar seperti Jakarta dan Semarang, namun kelengkapan variasi ini akan berbeda dibandingkan kota yang lebih kecil. Perbedaan karakter dan keunikan kasus studi ini menjadi dasar kebaruan pada artikel penelitian ini.

Sample kawasan yang digunakan dalam penelitian ini adalah: kota baru, kampung kota, pusat bisnis terpadu, kawasan pinggiran (urban fringe). Alasan pemilihan sample kawasan ini karena mewakili karakteristik morfologi pengembangan yang berbeda di Kota Surabaya. Karena perbedaan karakteristik ini akan menjadi menarik untuk diketahui perbedaan pada setiap tipologi. Sample kawasan ini dianalisis menggunakan deskriptifevaluasi dari teori dan hasil riset sebelumnya untuk dibaca dan dievaluasi menggunakan metode penilaian karakter.

\section{HASIL DAN PEMBAHASAN}

\section{A. Bentuk Tipologi Kota Surabaya}

Evaluasi morfologi Kota Surabaya ini menggunakan peta tahun 2021. Objek evaluasi struktur morfologi Kota Surabaya ini adalah: pola penggunaan lahan, pola jalan, dan persil bangunan (pola pengelompokan bangunan) (Gambar 1). Pembacaan morfologi Kota Surabaya berupa objek persil bangunan dianalisis menggunakan pembacaan karakter peta solid dan void dengan merujuk kepada teori figure and ground. Analisis menggunakan peta solid dan void merupakan teknik untuk membaca konfigurasi antara masa bangunan dan ruang terbuka. Dengan analisis menggunakan teori figure and ground dapat memahami bentuk pembangunan kota dan persebaran bangunan di perkotaan (Beirão dkk., 2015; Cavic dkk., 2017; Hebbert, 2016; Saner, 2014; Tallo dkk., 2014).

Menurut Trancik (1991) dan Zahnd (1999), terdapat enam pola tipologi massa bangunan dan ruang terbuka pada di perkotaan (Gambar 2). Pola angular yaitu pola yang terbentuk menyiku. Pola axial yaitu perkembangan bangunan yang tegak lurus terhadap bangunan monumentalism. Pola grid yaitu konfigurasi antara massa bangunan dan ruang yang dibentuk perpotongan jalan-jalan secara tegak lurus. Pola kurva linier adalah konfigurasi massa bangunan dan ruang secara linier (lurus menerus). Pola radial konsentris adalah konfigurasi massa dan ruang yang memusat. Pola organis adalah konfigurasi massa bangunan dan ruang yang terbentuk secara tidak beraturan.

Kota Surabaya yang dapat dianalisis merupakan kota yang memiliki pola konfigurasi massa bangunan dan ruang berbentuk organik. Dimana pola bangunan dan jalannya terbentuk secara natural dan tidak beraturan. Temuan ini didukung oleh penelitian dari (Damayanti (2015); Darjosanjoto (2005); Nuffida (2012)), bahwa dahulunya Kota Surabaya berkembang di pusat kota. Seiring bertambahnya waktu dan peningkatan ekonomi Kota Surabaya berkembang hingga pinggiran kota yang masih menyediakan lahan yang lebih luas. Dampaknya, Kota Surabaya tumbuh secara organik.

Temuan dari Barrington-Leigh and Millard-Ball (2020), menyimpulkan bahwa pengembangan kota-kota di Indonesia memiliki perkembangan spraw/ keluar pada era saat ini. Hal ini berlaku juga untuk Kota Surabaya. Meskipun saat ini perkembangan Kota Surabaya tumbuh keluar area (sprawl), namun kepadatan di Kota Surabaya tidak menjadi menyebar, karena kepadatan tertinggi tetap ada di sekitaran pusat kota (Gambar 5). 




Gambar 1. Analisis Pembacaan Karakter Tipologi Kota Surabaya (Solid dan Void)



Gambar 2. Pola konfigurasi massa bangunan (solid) dan ruang terbuka (void) Sumber: Zahnd (1999)

Menurut Morlok (1991) dan Putri dkk. (2016) terdapat 6 bentuk jaringan jalan yang pernah ada (Gambar 3), antara lain: Jaringan jalan grid yaitu jaringan jalan berbentuk kotak dan sudah direncanakan dari awal kota dikembangkan. Jaringan jalan radial merupakan bentuk yang menitik beratkan keterhubungan antar pusat bisnis terpadu. Jalan cincin radial bermodel lingkaran dengan harapan menghubungkan antara beberapa pusat kota melalui memutar pusat-pusat kemacetan. Jalan spinal berbentuk lurus dengan beberapa cabang dan merupakan tipe jalan untuk menghubungkan antar kota. Jaringan jalan hexagonal persimpangan jalan yang berpencar dan mengumpul tetapi tanpa melintang satu sama lainnya secara langsung. Jaringan jalan delta berbentuk tumpukan segitiga yang membentuk kesatuan.



Gambar 3. Jenis Jaringan Jalan Sumber: Morlok (1991)

Namun demikian, hasil analisis pembacaan menyatakan bahwa pola jalan di Kota Surabaya merupakan bentuk yang tidak berpola. Kota Surabaya memiliki pola diluar 6 bentuk jaringan 
jalan. Analisis ini didukung oleh temuan Putri dkk. (2016) bahwa kota dengan bentuk morfologi organik yang berkembang bebas dan tidak beraturan memiliki bentuk pola jaringan jalan yang tidak berpola. Hal ini berlaku untuk Kota Surabaya.

Meskipun morfologi Kota Surabaya tumbuh organis yang tidak berpola, tetapi di dalam Kota Surabaya terdapat kluster-kluster kawasan yang memiliki polanya (Gambar 4). Berdasarkan hasil evaluasi teori, ditemukan bahwa di Surabaya terdapat empat pola tipologi pengembangan, yaitu: tipologi kawasan kota baru, kampung kota, pusat bisnis terpadu, kawasan pinggiran untuk kelas pekerja (Damayanti, 2015; Fikriyah, 2013; Idawati, 2015; Kwanda, 2000; Navastara \& Mandasari, 2019; Putra \& Pradoto, 2016; Rahmadaniyati dkk., 2017; Santosa, 2008; Setijanti dkk., 2016; Shirleyana dkk., 2018; Silas, 1988; Silas \& Ernawati, 2013; Sistyaningsih \& Kisnarini, 2017).



Gambar 4. Peta Sample Lokasi Mewakili 4 Tipologi Pola Pengembangan di Surabaya yang Dianalisis dengan Penilaian Karakter

Sumber: Penggambaran Ulang Peta Kota Surabaya Tahun 2021

Dari peta Gambar 4, dapat dianalisis bahwa kawasan kampung kota memiliki kepadatan penduduk tertinggi, dan kawasan kota baru memiliki kepadatan terendah dari keseluruhan rata-rata
Kota Surabaya. Sedangkan CBD dan Urban Fringe memiliki kepadatan tengah diantara dua tipologi sebelumnya. 




Gambar 5. Evaluasi Statistika Kepadatan Penduduk Setiap Tipologi Dibandingkan Kepadatan Rata - Rata Kelurahan di Surabaya

Sumber: Dihitung Berdasarkan Data Profil Kelurahan dari Badan Pusat Statistika Tahun 2020

\section{B. Tipologi Kawasan Kota Baru}

Kawasan kota baru di Surabaya umumnya terletak di pinggiran. Menurut penelitian Fikriyah (2013) pengembangan kota baru oleh Developer Citra Land di Surabaya Barat mulai dilakukan sejak tahun 1993. Mula-mula pembangunan yang dilakukan adalah dengan pengembangan infrastruktur dan fasilitas-fasilitas lapangan golf serta sarana rekreasi. Pembangunan tersebut dilakukan seiring dengan ketentuan rancangan master plan daerah perbukitan Surabaya Barat sebagai kawasan hijau dan area rekreasi pada saat itu. Pembangunan ini diiringi dengan tumbuhnya hunian-hunian baru yang dikembangkan Developer Citra Land (Gambar 6).
Dalam perkembangannya kawasan ini tumbuh sebagai kota mandiri dengan segala fasilitasnya. Pembangunan perumahan Citra land dilengkapi dengan fasilitas komersial seperti niaga, perkantoran, hiburan, olahraga, dan rekreasi. Pembangunan fasilitas-fasilitas di Citra Land turut memberikan kontribusi bagi perkembangan Kota Surabaya.

Saat ini Kawasan Citra Land yang di klaim sebagai kawasan kota baru mandiri dengan integrasi berbagai sarana dan prasarana kota, seperti pendidikan, mall dan perkantoran dalam satu area pada pinggiran Kota Surabaya bagian barat dan bagian timur. 




Gambar 6. Analisis Tipologi Kawasan Kota Baru di Surabaya Barat Oleh Developer Yang di Dalamnya Terdapat Cluster Cluster

Sumber: Penggambaran Ulang Berdasarkan Open Street Map, Map Surfer ASTER GDEM - SRTM Hill Shade Tahun 2021

Saat ini, pada kawasan kota baru ini, ditemukan beberapa pola struktur bangunan. Pola struktur bangunan yang ada di kawasan kota baru ini adalah konvensional, kluster dan planned unit development (PUD) dengan kepadatan kapling bangunan yang rendah (Gambar 7).
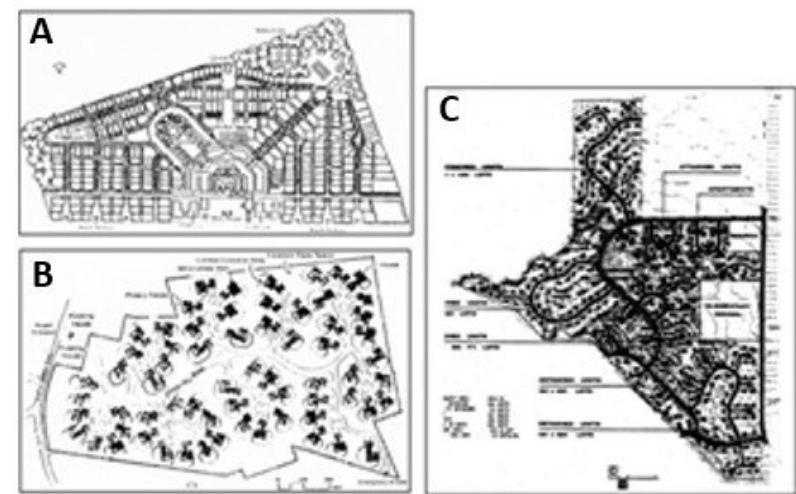

Gambar 7. (A) Konsep Konvensional, (B) Konsep Kluster, (C) Konsep Planned Unit Development. Sumber : Kwanda (2000)

Pola konvensional di kota baru memiliki tingkat kepadatan rumah sama seperti pola kluster namun batasan kapling yang jelas dan bentuk kapling yang relatif sama tersebar secara merata pada keseluruhan lahan.

Pada kluster, rumah dibangun secara berkelompok untuk mendapatkan kepadatan yang tinggi pada suatu area, sehingga lahan lainnya dapat dimanfaatkan untuk ruang terbuka. Konsep PUD yang ada di kota baru merupakan suatu pengembangan multi fungsi yang fleksibel tanpa ada pembagian yang kaku untuk setiap zona kegiatan, dalam suatu unit lahan dapat dikombinasikan semua kegiatan seperti perumahan dengan berbagai tipe, perkantoran, pertokoan, rekreasi dan ruang terbuka (Kwanda, 2000).

Untuk pola jalan, terdapat berbagai jenis pola jalan yang ada pada studi perkotaan (Rifaat dkk., 2012; Southworth \& Ben-Joseph, 2013). Pola tersebut dapat dilihat pada Gambar 8. 




Gambar 8. Pola - Pola Jalan

Sumber: Southworth \& Ben-Joseph (2013)

Pola grid adalah sistem sederhana dari dua rangkaian jalan paralel yang bersilangan tegak lurus membentuk pola balok persegi panjang. Pola paralel terfragmentasi memiliki blok yang di konfigurasi ulang menjadi persegi panjang dan bentuk $L$ yang panjang dan sempit. Pola paralel melengkung terdiri dari jalan melengkung di blok panjang dan sempit, persimpangan $T$ dan sudut $L$. Pola loop dan lollipop ditandai dengan adanya loop dan cul-de-sac. Loop dan lollipop menciptakan pola jalan non-arah yang cenderung berputar ke belakang. Lollipop pada pola stick street dibentuk dengan mencabangkan cul-de-sac buntu (Rifaat dkk., 2012; Southworth \& Ben-Joseph, 2013) (Gambar 9).

Berdasarkan analisis penilaian karakter, pola jalan yang terbentuk di dalam kawasan kota Baru adalah kombinasi pola kotak, pola loop dan pola cul-de-sac. Hasil analisis ini didukung oleh temuan dari penelitian Kwanda (2000), bahwa di kota baru ditemukan pola grid yang memiliki bentuk kapling yang praktis and efisien. Pola cul-de-sac yang memiliki bentuk kapling yang tidak beraturan dengan bentuk jalan buntu yang menciptakan pengelompokan rumah, dan dengan batasan jumlah rumah yang dilayani sehingga akan tercipta dimensi jalan yang ekonomis, yaitu dimensi lebar jalan lebih kecil. Rancangan pola putaran dan pola loop dengan taman biasanya terletak di tengah untuk menciptakan pengelompokan rumah.

Menurut temuan dari Kwanda (2000), pola permukiman di kawasan kota baru pada umumnya bertipe grid dan kotak, dengan sebagian kecil permukiman elite menggunakan pola cul-de-sac yang ditemukan pada perumahan Darmo golf, bukit golf di kawasan kota baru Surabaya Barat.



Gambar 9. Pola Jalan di Kota Baru Sumber : Kwanda (2000)

Konsep awal kota baru sebenarnya adalah menciptakan kawasan kompak. Ada tiga indikator yang digunakan sebagai kriteria dalam mengukur kota tersebut kompak atau tidak, yaitu: kepadatan tinggi, penggunaan lahan campuran, dan adanya intensifikasi. Kepadatan mencakup kepadatan penduduk, kepadatan terbangun dan kepadatan pemukiman. Indikator lahan campuran terdiri dari tingkat ketersediaan pelayanan sekolah dasar, pelayanan sekolah menengah atas, pelayanan sekolah menengah pertama, pelayanan fasilitas kesehatan, jumlah tenaga medis (dokter, dokter gigi, dan perawat), persentase kantor atau wilayah kerja, dan persentase ruang rekreasi atau ruang bebas atau hijau dalam variabel penggunaan lahan. Terakhir adalah indikator intensifikasi yang mencakup variabel laju pertumbuhan penduduk dan laju migrasi (Burton, 2000; Kurniadi, 2007; Neuman, 2005; Sadikin, 2009; Zia \& Rho, 2014).

Jika merujuk kepada tiga indikator ini, dapat dianalisis bahwa guna lahan, kawasan kota baru menyediakan sekolah, rumah sakit, kantor, ruang terbuka. Namun menurut penelitian Fikriyah (2013), permukiman di kawasan kota baru ini umumnya adalah permukiman kelas menegah dengan harga tanah yang mahal dan di konsep mulai awal oleh pengembang. Warga kelas menegah ke bawah yang biasanya hidup di kampung dengan kepadatan sangat tinggi akan tersisih keluar dari kawasan kota baru. Tidak ada integrasi antara masyarakat ekonomi kelas atas dan ekonomi ke bawah, yang terjadi.

Menurut O'Sullivan (2011), penduduk berpenghasilan tinggi akan memiliki nilai-nilai lingkungan yang lebih tinggi karena kemampuan untuk membayar pajak, sehingga fasilitas di lingkungan tempat tinggal mereka akan memiliki 
nilai-nilai yang lebih tinggi, misalnya dengan adanya ruang publik yang nyaman, taman yang indah, jaringan jalan yang luas dan lebih mudah diakses dan keamanan lingkungan yang tinggi daripada penduduk berpenghasilan rendah.

Dari hasil analisis pembacaan karakter tata guna lahan ditemukan bahwa kawasan kota baru telah mengintegrasikan permukiman, perdagangan dan perkantoran di dalam suatu kawasan, hanya saja, tidak ada konsep kepadatan dan penggunaan campuran yang terbentuk antar berbagai kelas sosial masyarakat. Tidak ada perencanaan kota kompak pada kawasan kota baru. Dimana seharusnya konsep penggunaan campuran dan kepadatan adalah menciptakan integrasi antar berbagai ekonomi, antara kawasan elite dan kampung yang difasilitasi sarana prasarana yang sama.

\section{Tipologi Kawasan CBD}

Kawasan CBD, sebagai 'jantung kota' terletak di bagian tengah Kota Surabaya, dengan fungsi kegiatan, seperti bank, kantor, hotel, bioskop, dan teater. Studi klasik dalam geografi perkotaan mendefinisikan $C B D$ sebagai lahan yang berisi konsentrasi aktivitas pusat tertinggi dan bernilai tinggi (Yu dkk., 2015). Konsep kawasan CBD merupakan pengembangan dari teori klasik karya Burgess (2011) bahwa kawasan CBD merupakan pemusatan ritel, perdagangan, bisnis, pertokoan dan mall. Tipologi CBD memiliki bangunan vertikal, menjulang tinggi, jalan yang lebar, jalur pejalan kaki yang luas, tidak ada kawasan permukiman di dalam zona CBD dan tidak terdapat daerah industri pabrik (Navastara \& Mandasari, 2019; Sistyaningsih \& Kisnarini, 2017; Yaguang, 2011).



Gambar 10. Analisis Tipologi Pola Bangunan, Jalan dan Guna Lahan di Kawasan CBD

Sumber: Penggambaran Ulang Berdasarkan Open Street Map, Map Surfer ASTER GDEM - SRTM Hill Shade Tahun 2021

Berdasarkan analisis pembacaan karakter yang dievaluasi berdasarkan penelitian (Navastara and Mandasari (2019); Sistyaningsih and Kisnarini (2017); Yaguang (2011)), tipologi Kawasan CBD Surabaya didominasi bangunan vertikal dan di sepanjang CBD tersebut ditemukan jalur pejalan kaki yang lebar. Hasil analisis tata guna lahan kawasan CBD, Bahwa kawasan ini didominasi oleh perdagangan dan jasa, perkantoran dan perhotelan (Gambar 10).

Menurut penelitian dari Navastara and Mandasari (2019), bahwa pedestrian way di kawasan CBD surabaya memiliki jenis klasifikasi arcade dengan panjang rute 197 meters $(0,01 \mathrm{~km})$ dan trotoar sepanjang $2.084,43$ meters $(0,2 \mathrm{~km})$. Jalur pejalan 
kaki dalam istilah tipe arcade adalah ruang pejalan kaki yang berdekatan dengan bangunan di salah satu atau kedua sisinya.

\section{Berdasarkan analisis ketinggian bangunan} kawasan CBD Kota Surabaya, diperoleh hasil bahwa di kawasan ini didominasi oleh ketinggian bangunan $250 \mathrm{~m}$ dan tersebar di sepanjang koridor jalan intinya (Gambar 11). Temuan ini mendukung teori Sistyaningsih and Kisnarini (2017); Yaguang (2011), bahwa di kawasan CBD umumnya banyak terdapat bangunan vertikal.



Gambar 11. Analisis Ketinggian Bangunan Kawasan CBD Sumber: Peta RDTR Kota Surabaya tahun 2021

\section{Tipologi Kawasan Kampung Kota (Inner city)}

Sampling kampung kota yang dianalisis adalah kampung Peneleh. Kampung Peneleh terletak di pusat Kota Surabaya. Tipologi kampung Peneleh adalah kepadatan tinggi, jalan kecil didepan rumah sebagai ruang komunal tempat interaksi, ditandai dengan keberadaan balai atau pos ronda, jalanan sempit dan bentuk jalan terbentuk secara acak (organik).

Berbeda dengan konsep perencanaan yang diadopsi dari literatur barat tentang konsep perencanaan model konvensional, kluster dan planned unit development (PUD). Kampung kota memiliki tipologi tersendiri, karena tipologi kampung kota tidak ditemukan di literatur barat. Kawasan kampung kota tidak memilki pengaturan bentuk kaveling yang sama dan pengaturan zonasi yang ditentukan sejak awal (organik).

Menurut temuan dari (Damayanti (2015); Putra and Pradoto (2016); Santosa (2008); Setijanti dkk. (2016); Shirleyana dkk. (2018); Silas (1988); Silas and Ernawati (2013)), kampung kota di Kota Surabaya menampilkan pola jalan yang tidak teratur dan gang-gang sempit. Infrastruktur dan fasilitas dasar tersedia secara komunal di kampung. Beberapa kampung memiliki gang-gang sempit di pintu masuk pemukiman tetapi jalan 
gang yang lebih luas dan ruang terbuka di dalamnya untuk mengakomodasi fungsi sosial dan rekreasi.

Kampung yang terletak di pusat kota dan urban fringe memiliki perkembangan yang berbeda. Analisis ini didukung oleh penelitian Shirleyana dkk. (2018), dimana kampung kota yang terletak di sebelah kawasan CBD memiliki karakternya tersendiri. Kampung ini terletak di pinggir jalan, di belakang menara, pusat perbelanjaan, perkantoran, dan toko atau fasilitas komersial lainnya. Sirkulasi kampung menggunakan jaringan gang kecil dengan pola tidak beraturan untuk menghubungkan satu kampung dengan lainnya.

Kampung dalam kota telah ada sejak Keraton Surabaya dibangun. Proyek pembangunan perkotaan besar yang mendominasi kawasan pusat Kota Surabaya dan kawasan pusat bisnis menjadikan keberadaan kampung ini di masa depan tidak pasti. Banyak rumah kampung yang dijual atau dihuni oleh para pendatang dan beberapa bekas tempat tinggal sekarang berfungsi sebagai rumah kos, meskipun kampung dalam kota telah terdaftar sebagai kampung warisan.

Contoh kampung dalam kota adalah Kampung Kebangsren, Ketandan, Peneleh, dan Lawang Seketeng (Damayanti, 2015; Kwanda, 2000; Putra \& Pradoto, 2016; Santosa, 2008; Setijanti dkk., 2016; Shirleyana dkk., 2018; Silas, 1988; Silas \& Ernawati, 2013).



Gambar 12. Analisis Tipologi Kampung Kota Dengan Pembangunan Yang Organik dan Tumbuh Secara Natural Sumber: Penggambaran Ulang Berdasarkan Open Street Map, Map Surfer ASTER GDEM - SRTM Hill Shade Tahun 2021

Pola guna lahan yang homogen, hanya untuk tempat bermukim (Putra \& Pradoto, 2016). Dari analisis pembacaan karakter guna lahan di kampung kota, menunjukkan bahwa sebagian besar lahan kawasan kampung kota adalah permukiman dengan kepadatan tinggi (Gambar 12), sebagian kecil jasa toko kelontong di dalam kampung. Toko besar terdapat di sepanjang jalan utama bukan di dalam kampung. Temuan ini didukung oleh hasil penelitian (Damayanti (2015); Putra and Pradoto (2016); Shirleyana dkk. (2018)) yang menyatakan bahwa guna lahan dominan kampung Kota Surabaya adalah permukiman dengan status warga adalah ekonomi menengah ke bawah.

\section{E. Tipologi Kawasan Urban fringe}

Sampling tipologi kawasan pinggiran ini masuk pada administratif kelurahan Kalirungkut dan Gunung Anyar. Tipologi kawasan permukiman pinggiran Kota Surabaya terbagi menjadi dua, 
yaitu permukiman yang dikembangkan oleh developer seperti perumnas dan perkampungan pinggiran.

Menurut temuan penelitian Maharani and Umilia (2014), kawasan permukiman urban fringe ini merupakan permukiman kelas pekerja yang ada di Surabaya. Kawasan ini merupakan perluasan hasil pengembangan keluar Kota Surabaya. Pergeseran fungsi-fungsi kekotaan ke daerah pinggiran kota (urban fringe) yang disebut dengan proses perembetan penampakan fisik kekotaan ke arah luar (urban sprawl).

Perluasan kota menuju kawasan terluar merupakan penyebab adanya proses transformasi spasial berupa proses densifikasi permukiman dan transformasi sosial ekonomi di daerah pinggiran kota (Giyarsih, 2015).

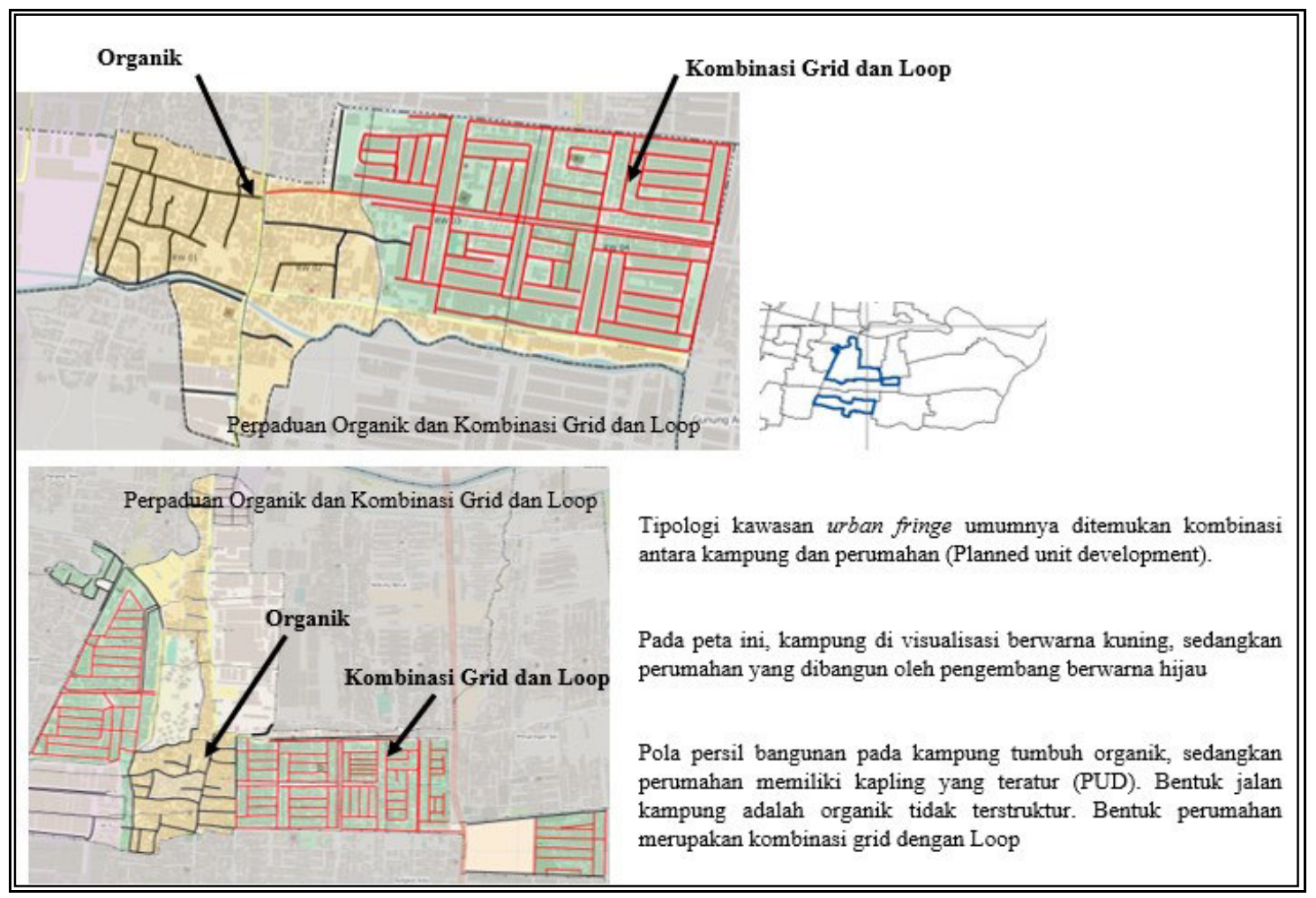

Gambar 13. Analisis Tipologi Urban Fringe dengan Pembangunan Campuran

Sumber: Penggambaran Ulang Berdasarkan Open Street Map, Map Surfer ASTER GDEM - SRTM Hill Shade Tahun 2021

Berdasarkan pembacaan karakter, ada dua kombinasi tipologi di kawasan pinggiran ini, yaitu: tipologi kampung pinggiran yang sifatnya organik dan tipologi perumahan yang sifatnya terencana. Tipologi perumahan terencana yang dikembangkan oleh developer di pinggiran (urban fringe) memiliki konsep perencanaan konvensional yaitu batasan kapling yang jelas dan bentuk kapling yang relatif sama tersebar secara merata pada keseluruhan lahan, pola jaringan jalannya adalah pola kotak dan pola putaran. Sedangkan untuk tipologi perkampungan di pinggiran kota, secara garis besar memiliki tipologi yang sama dengan kampung yang ada di pusat Kota Surabaya yaitu tumbuh organik. Namun demikian kampung pinggiran memiliki karakteristik sejarah perkembangan yang berbeda. Temuan ini didukung oleh temuan penelitian dari (Maharani and Umilia (2014); Shirleyana dkk. (2018)) bahwa perkampungan pinggiran di Surabaya memiliki karakteristik organik yang mirip dengan kampung di sekitaran pusat kota (Gambar 13). 
Adapun perbedaan dan persamaan antara kampung kota dan pinggiran, yaitu: untuk persamaannya adalah tidak memilki pengaturan bentuk kaveling yang sama dan pengaturan zonasi yang direncanakan sejak awal, pola jalan yang tidak teratur dan gang-gang sempit. Perkampungan ini memiliki kepadatan yang tinggi.

Temuan penelitian dari (Maharani and Umilia (2014); Shirleyana dkk. (2018)) yang di lakukan pada perbatasan selatan dan barat di Kota Surabaya menyatakan karakteristik kampung di sini membentuk pemukiman linier, terletak di sepanjang jalan arteri utama. Kampung pinggiran kota memiliki kepadatan lebih rendah daripada pusat Kota Surabaya, berkisar antara 2.000 hingga 3.500 jiwa per kilometer persegi. Kampung pinggiran umumnya memiliki lebar jalan bervariasi dari 4 hingga 8 meter. Kampung pinggiran kota terbuka untuk ekspansi karena dikelilingi oleh banyak lahan kosong dan lahan pertanian. Contoh kampung pinggiran kota antara lain: Kampung Jambangan, Gunung Anyar, dan Darmokali.

Risiko sosial, fisik, ekonomi, dan lingkungan menonjol di sebagian besar kampung pinggiran kota. Risiko sosial meliputi: rawan untuk digusur oleh pembangunan developer besar, konflik sosial karena ekonomi dan budaya, kriminalitas dan status keamanan. Risiko fisik meliputi: spekulasi tanah, desakan pembangunan, kurangnya ruang publik untuk interaksi, lingkungan yang sempit, kekurangan tanah dan jalan buntu, komersialisasi rumah sebagai kos yang menyebabkan lingkungan bertambah padat. Risiko ekonomi, meliputi: hilangnya mata pencaharian karena banjir, keragaman sosial tidak didukung pemerintah kota, pekerjaan tidak pasti dan penghasilan tidak tetap. Risiko lingkungan meliputi : terlalu sesak, banjir, buruknya sanitasi (Damayanti \& Kossak, 2016; Hellman, 2015; Maharani \& Umilia, 2014; Peters, 2013; Rahmadaniyati dkk., 2017; Rolalisasi dkk., 2013; Santosa, 2008; Setijanti dkk., 2016; Shirleyana dkk., 2018; Silas \& Ernawati, 2013).

Dari hasil evaluasi ditemukan bahwa kepadatan kampung pinggiran lebih rendah daripada kampung di pusat kota. Tata guna lahan pada kawasan urban fringe banyak ditemui perumahan yang dibangun developer dengan skala kecil dan bersebelahan dengan kampong-kampung. Sarana dan prasarana mengikuti perkembangan kampung dan perumahan skala kecil ini.

Analisis pembacaan karakter untuk tata guna lahan pada kawasan pinggiran menunjukkan bahwa kawasan ini didominasi oleh permukiman bagi para pekerja kantoran dan informal di Surabaya. Guna lahan berupa jasa seperti toko atau supermarket juga dapat ditemukan di sekitar lokasi tetapi bukan guna lahan dominan.

Temuan analisis tipe urban fringe ini sejalan dengan penelitian Giyarsih (2015), kawasan urban fringe merupakan kawasan yang disenangi sebagai hunian karena memiliki harga lahan yang murah dibandingkan di tengah kota dan memiliki area yang relatif lebih luas daripada di pusat kota.

\section{KESIMPULAN}

Kota Surabaya memiliki empat variasi tipologi, antara lain: kawasan kota baru dengan skala besar oleh developer (superblock). Tipologi kawasan CBD guna lahan untuk perkantoran, perdagangan dan jasa. Kawasan kampung kota yang tumbuh organik. Kawasan pinggiran yang memiliki kombinasi tipologi di dalamnya, yaitu perumahan skala kecil yang dibangun oleh developer. Pada area urban fringe, perumahan-perumahan ini umumnya akan bersebelahan dengan kampung dengan tipologi organik.

Tabel 1. Kesimpulan Pola Pembangunan di Kota Surabaya

\begin{tabular}{|c|c|c|c|}
\hline Tipologi & Tata guna lahan & Pola jalan & Pola bangunan \\
\hline CBD & $\begin{array}{l}\text { - Homogen } \\
\text { bangunan } \\
\text { perdagangan } \\
\text { jasa } \\
\text { - Dominasi } \\
\text { bangunan } \\
\text { vertikal }\end{array}$ & $\begin{array}{l}\text { kombinasi } \\
\text { pola kotak, } \\
\text { pola loop } \\
\text { dan pola } \\
\text { cul-de-sac }\end{array}$ & $\begin{array}{l}\text { - Kepadatan } \\
\text { kapling sedang. } \\
\text { - Model } \\
\text { bangunan } \\
\text { Vertikal } \\
\text { - Pola } \\
\text { konvensional } \\
\text { yang } \\
\text { direncanakan } \\
\text { dengan } \\
\text { mengikuti jalan } \\
\text { lurus utama }\end{array}$ \\
\hline Kota baru & $\begin{array}{l}\text { - Campuran, } \\
\text { perdagangan, } \\
\text { permukiman, }\end{array}$ & $\begin{array}{l}\text { kombinasi } \\
\text { pola kotak, } \\
\text { pola loop }\end{array}$ & $\begin{array}{l}\text { - Konvensional } \\
\text { - Kluster }\end{array}$ \\
\hline
\end{tabular}




\begin{tabular}{|c|c|c|c|}
\hline Tipologi & $\begin{array}{l}\text { Tata guna lahan } \\
\text { pendidikan, } \\
\text { perkantoran } \\
\text { dan jasa }\end{array}$ & $\begin{array}{l}\text { Pola jalan } \\
\text { dan pola } \\
\text { cul-de-sac }\end{array}$ & $\begin{array}{l}\text { Pola bangunan } \\
\text { - Planned unit } \\
\text { development } \\
\text { (PUD) } \\
\text { - Memiliki } \\
\text { kepadatan } \\
\text { kapling } \\
\text { rendah }\end{array}$ \\
\hline $\begin{array}{l}\text { Kampung } \\
\text { kota }\end{array}$ & $\begin{array}{l}\text { - Dominasi oleh } \\
\text { permukiman } \\
\text { penduduk } \\
\text { - Toko } \\
\text { kelontong dan } \\
\text { warung di } \\
\text { dalam } \\
\text { kampung }\end{array}$ & $\begin{array}{l}\text { Dominasi } \\
\text { grid dan } \\
\text { sebagian } \\
\text { kecil loop }\end{array}$ & $\begin{array}{l}\text { - } \text { Tidak } \\
\text { beraturan } \\
\text { - } \text { organik }\end{array}$ \\
\hline $\begin{array}{l}\text { Urban } \\
\text { fringe }\end{array}$ & $\begin{array}{l}\text { - Kombinasi } \\
\text { antara } \\
\text { kampung dan } \\
\text { perumahan } \\
\text { sakal kecil } \\
\text { seperti } \\
\text { perumnas } \\
\text { - Disebelah } \\
\text { perumahan } \\
\text { nasional dapat } \\
\text { tumbuh } \\
\text { kampung }\end{array}$ & $\begin{array}{l}\text { - Tidak } \\
\text { berstruktur } \\
\text { atau } \\
\text { organik } \\
\text { pada } \\
\text { kampung } \\
\text { - Grid dan } \\
\text { loop pada } \\
\text { perumahan } \\
\text { nasional }\end{array}$ & $\begin{array}{l}\text { - Konvensional } \\
\text { pada } \\
\text { perumahan } \\
\text { nasional } \\
\text { - Organik atau } \\
\text { tidak } \\
\text { terencana } \\
\text { pada } \\
\text { kampung } \\
\text { - Kepadatan } \\
\text { kapling } \\
\text { kampung } \\
\text { tinggi dan } \\
\text { kepadatan } \\
\text { kapling } \\
\text { perumahan } \\
\text { sedang }\end{array}$ \\
\hline
\end{tabular}

Konsep guna lahan kota kompak yang digunakan oleh developer dalam mengembangkan kota baru di Kota Surabaya selama ini hanya merek dagang atau strategi pengembang, sebenarnya menurut teori (Burton (2000); Kurniadi (2007); Neuman (2005); Sadikin (2009); Zia and Rho (2014)), bahwa kota kompak harus mixed used dengan mengintegrasikan antara setiap elemen masyarakat. Namun demikian, pada kota baru di Surabaya, kawasan ini dihuni oleh masyarakat berpenghasilan menengah ke atas yang merupakan kawasan elite di Surabaya, sehingga ada segregasi spasial antara kelas ekonomi. Di dalam teori ekonomi spasial kota oleh O'Sullivan (2011), fenomena segregasi ini muncul karena berbagai faktor, meliputi: fenomena kemiskinan, penduduk berpenghasilan tinggi tinggal di pinggiran dan mengembangkan kawasan yang disukai.

\section{DAFTAR PUSTAKA}

Al-Saaidy, H. J. E. (2020). Urban Form Elements and Urban Potentiality (Literature Review). Journal of Engineering, 26(9), 6582. Doi: 10.31026/j.eng.2020.09.05

Barke, M. (2018). The Importance of Urban Form as an Object of Study Teaching Urban Morphology (pp. 11-30): Springer.

Barrington-Leigh, C., \& Millard-Ball, A. (2020). Global Trends Toward Urban StreetNetwork Sprawl. Proceedings of the National Academy of Sciences, 117(4), 1941-1950. Doi: https://doi.org/10.1073/ pnas.1905232116

Beirão, J. N., Chaszar, A., \& Čavić, L. (2015). Analysis and Classification of Public Spaces Using Convex and Solid-Void Models Future City Architecture for Optimal Living (Vol. 102, pp. 241-270): Springer.

Burgess, E. W. (2011). "The Growth of the City: An Introduction to a Research Project": from Robert E. Park, Ernest W. Burgess, and Roderick D. McKenzie, The City (1925) The City Reader (pp. 207-215): Routledge.

Burton, E. (2000). The Compact City: Just or Just Compact? A Preliminary Analysis. Urban studies, 37(11), 1969-2006. Doi: https://doi.org/10.1080/0042098005016 2184

Cavic, L., Šileryte, R., \& Beirão, J. (2017). 3dInformed Convex Spaces: The Automated Generation of Convex Representation for Open Public Space Analysis. Paper presented at the Proceedings of the 11th International Space Syntax Symposium, Instituto Superior Técnico, Departamento de Engenharia Civil, Arquitetura e Georrecursos, Portugal.

Chan, S. H., Donner, R. V., \& Lämmer, S. (2011). Urban Road Networks-Spatial Networks With Universal Geometric Features? The European Physical Journal B, 84(4), 563577. Doi: https://doi.org/10.1140/epjb/ e2011-10889-3 
Chen, F. (2014). Urban Morphology and Citizens' Life. In A. C. Michalos (Ed.), Encyclopedia of Quality of Life and Well-Being Research. Netherlands: Springer

Chen, T., Hui, E. C., Wu, J., Lang, W., \& Li, X. (2019). Identifying Urban Spatial Structure and Urban Vibrancy In Highly Dense Cities Using Georeferenced Social Media Data. Habitat International, 89, 102005. Doi: https://doi.org/10.1016/j.habitatint.2019 .102005

Chen, W., Wu, A. N., \& Biljecki, F. (2021). Classification of Urban Morphology with Deep Learning: Application on Urban Vitality. Computers, Environment and Urban Systems, 2-29. Doi: https://doi.org/10.1016/j.compenvurbsys .2021 .101706

Chua, H. L., Lee, S. H., \& Fulmer, G. W. (2017). Action Research on The Effect of Descriptive and Evaluative Feedback Order on Student Learning in A Specialized Mathematics and Science Secondary School. Asia-Pacific Science Education, 3(1), 1-22. Doi: https://doi.org/10.1186/ s41029-017-0015-y

Creswell, J. W. (2017). Research Design: Qualitative, Quantitative, and Mixed Methods Approaches (4th ed): Sage publications.

Damayanti, R. (2015). Extending Kevin Lynch's Theory of Imageability; Through an Investigation of kampungs in SurabayaIndonesia. (Doctoral), University of Sheffield.

Damayanti, R., \& Kossak, F. (2016). Examining Spatial Identity of Kampungs Through Young Adults' Perception in SurabayaIndonesia. Journal of Architecture and Urbanism, 40(1), 18-28. Doi: https://doi.org/10.3846/20297955.2016. 1150222

Darjosanjoto, E. T. S. B. (2005). Kembang Jepun: Jalan Dominan Kota Surabaya. DIMENSI (Journal of Architecture and Built Environment), 33(2).

Dempsey, N., Brown, C., Raman, S., J, S. P. M., Bramley, C. J., \& Gabe, R. T. (2008). Sustainable City Form (M. Jenks \& C. Jones (eds.); Vol. 2): Springer Netherlands.
Dempsey, N., Brown, C., Raman, S., Porta, S., Jenks, M., Jones, C., \& Bramley, G. (2010). Elements of Urban Form Dimensions of the Sustainable City (Vol. 2, pp. 21-51): Springer.

Dharmayana, I. W., \& Herawati, A. A. (2021). Descriptive Evaluative Study on the Implementation of Online Learning During the COVID-19 Pandemic in the Courses of Guidance and Counseling Profession. Paper presented at the International Conference on Educational Sciences and Teacher Profession (ICETeP 2020).

Ding, W. (2013). Urban Design Needs Urban Morphology: A Practitioner's Viewpoint. Urban Morphology, 17(2), 120-123.

Fikriyah, S. (2013). Perkembangan Kawasan Realestate di Surabaya Barat Tahun 19702000 (Kontribusi Citraland dalam Perkembangan Kawasan Realestate di Surabaya Barat). Avatara, 1(3).

Giyarsih, S. R. (2015). Gejala Urban Sprawl Sebagai Pemicu Proses Densifikasi Permukiman di Daerah Pinggiran Kota (Urban Fringe Area). Jurnal Perencanaan Wilayah dan Kota, 12(1), 40-45.

Han, B., Sun, D., Yu, X., Song, W., \& Ding, L. (2020). Classification of Urban Street Networks Based on Tree-Like Network Features. Sustainability, 12(2), $628 . \quad$ Doi: https://doi.org/10.3390/su12020628

Hebbert, M. (2016). Figure-Ground: History and Practice of A Planning Technique. Town Planning Review, 87(6), 705-728. Doi: https://doi.org/10.3828/tpr.2016.44

Hellman, J. (2015). Living With Floods and Coping With Vulnerability. Disaster Prevention and Management, 24(4), 468-483. Doi: https://doi.org/10.1108/DPM-04-20140061

Idawati, D. E. (2015). A Case of Urban Mimicry: Citra Raya, The Singapore of Surabaya. Journal of Architecture \& Environment, 14(1), 19-32. Doi: https://doi.org/10. 12962/j2355262x.v14i1.a884

Indahri, Y. (2017). Tantangan Pengelolaan Penduduk di Kota Surabaya. Aspirasi: Jurnal Masalah-masalah Sosial, 8(1), 1-11. Doi: 10.46807/aspirasi.v8i1.1251 
Kantun, S. (2017). Penelitian Evaluatif Sebagai Salah Satu Model Penelitian Dalam Bidang Pendidikan (Suatu Kajian Konseptual). JURNAL PENDIDIKAN EKONOMI: Jurnal Ilmiah Ilmu Pendidikan, Ilmu Ekonomi dan IImu Sosial, 10(2), 15.

Kurniadi, I. (2007). Pola Spasial Urban Compaction di Wilayah Metropolitan Bandung. (Tugas Akhir ), Departemen Teknik Planologi-ITB, Bandung.

Kwanda, T. (2000). Penerapan Konsep Perencanaan dan Pola Jalan Dalam Perencanaan Realestat 1 di Surabaya. Dimensi : Journal of Architecture and Built Environment, 28(2). Doi: https://doi.org/ 10.9744/dimensi.28.2.\%25p

Maharani, L. A., \& Umilia, E. (2014). Tipologi Permukiman Kumuh di Pinggiran Selatan Kota Surabaya. Jurnal Teknik ITS, 3(2), C102-C106.

Morlok, E. K. (1991). Pengantar Teknik dan Perencanaan Transportasi. Jakarta: Erlangga.

Moudon, V. (1994). Getting to Know The Built Landscape: Typomorphology: Van Nostrand Reinhold.

Navastara, A., \& Mandasari, V. (2019). Sustainable pedestrian ways in Central Business District of Tunjungan Surabaya: Can principles of new urbanism be applied? Paper presented at the IOP Conference Series: Earth and Environmental Science.

Neuman, M. (2005). The Compact City Fallacy. Journal of Planning Education and Research, 25(1), 11-26. Doi: https://doi.org/10.1177/0739456X04270 466

Nuffida, N. E. (2012). Tipogenesis Struktur Ruang Kota Nusantara: Kajian dan Definisi dengan Referensi Studi Kota Surabaya 1870-2010 berdasarkan Pergerakan Aktivitas Sosial-Ekonomi Warga Kota. Paper presented at the Seminar Nasional Semesta Arsitektur Nusantara-1 (SAN-1).

O'Sullivan, A. (2011). Urban Economics: McGrawHill Education.

Ostad-Ali, F., Behzadi, M. H., \& Shahvarani, A. (2015). Descriptive Qualitative Method of
Evaluation from The Viewpoint of Math Teachers and Its Comparison With The Quantitative Evaluation (Giving Scores) Method (A Case Study on The Primary Schools For Girls in Zone 1 of Tehran City). Mathematics Education Trends and Research, 1, 50-56. Doi: https://doi.org/10.5899/2015/metr00078

Peters, R. (2013). Surabaya, 1945-2010: Neighbourhood, State And Economy in Indonesia's City of Struggle: NUS Press Pte Ltd.

Putra, D. R., \& Pradoto, W. (2016). Pola dan Faktor Perkembangan Pemanfaatan Lahan di Kecamatan Maranggen, Kabupaten Demak. Jurnal Pengembangan Kota, 4(1), 66-74.

Doi: http://dx.doi.org/10.14710/jpk.4.1.66-74

Putra, R. D. W. (2017). Kajian Place Attachment di Kampung Pecinan Tambak Bayan Tengah, Kota Surabaya. Region: Jurnal Pembangunan Wilayah dan Perencanaan Partisipatif, 7(1), 19-26. Doi: https://doi.org/10.20961/region.v7i1.578 0

Putri, M. A., Rahayu, M. J., \& Putri, R. A. (2016). Bentuk Morfologi Kawasan Permukiman Urban Fringe Selatan Kota Surakarta. Jurnal Pengembangan Kota, 4(2), 120128. Doi: 10.14710/jpk.4.2.120-128

Rahmadaniyati, D., Widyasari, A., Kisnarini, R., \& Sumartinah, H. (2017). The Inner-City Kampung Development Concept As Sustainable Tourism Area in Surabaya, Indonesia. International Journal of Engineering Research \& Technology, 6(01), 114-119.

Rifaat, S. M., Tay, R., \& de Barros, A. (2012). Urban Street Pattern and Pedestrian Traffic Safety. Journal of urban design, 17(3), 337-352. Doi: https://doi.org/10.1080/ 13574809.2012.683398

Rolalisasi, A., Happy, S., \& Ispurwono, S. (2013). Social Capital of Urban Settlement. Psychology and Behavioral Sciences, 2(3), 83. Doi: https://doi.org/10.11648/j.pbs. 20130203.11 
Sadikin, A. (2009). Konsep Penataan Spasial Pelayanan Pendidikan Untuk Jenjang SMP di Surabaya Berdasarkan Indikator Kota kompak., Institut Teknologi Sepuluh Nopember.

Sanders, P. (2013). Towards Consonance in Urban Form. Urban Morphology, 17(2), 116-118.

Sanders, P., \& Baker, D. (2016). Applying Urban Morphology Theory to Design Practice. Journal of urban design, 21(2), 213-233. Doi: https://doi.org/10.1080/13574809. 2015.1133228

Saner, M. (2014). A Philosophy of Void: Ankara Hippodrome and After. Published Doctorate's thesis, Faculty of Architecture. Middle East Technical University. Ankara.

Santosa, H. (2008). Linking Open Building and Sustainable Livelihoods in The KampungInformal Settlement. Paper presented at the Proceeding of the Joint Conference of CIB W.

Santoso, L. S. (2017). Etnografi Warung Kopi: Politik Identitas Cangkrukan di Kota Surabaya dan Sidoarjo. Mozaik Humaniora, 17(1), 113. Doi: http://dx. doi.org/10.20473/mozaik.v17i1.6594

Sasongko, R. N. (2018). The Implementation of National Standards of Education for School Quality Improvement Facing The 21st Century (Descriptive Evaluative Studies in Various Levels of Schools in Bengkulu Province of Indonesia). International Journal of Current Research in Life Sciences, 7(08), 2647-2651.

Schirmer, P. M., \& Axhausen, K. W. (2016). A Multiscale Classification of Urban Morphology. Journal of Transport and Land Use, 9(1), 101-130. Doi: https://doi.org/10.5198/jtlu.2015.667

Setijanti, P., Santosa, H., Krisdiiato, J., Salatoen, M., Firmaningtyas, S., Ernawati, R., \& Bahari. (2016). Creating Built Environments of New Opportunities. Paper presented at the The CIB World Building Congress.

Sharifi, A., \& Yamagata, Y. (2018). Resilient Urban Form: A Conceptual Framework Resilience-Oriented Urban Planning (pp. 167-179): Springer.
Shirleyana, S., Hawken, S., \& Sunindijo, R. Y. (2018). City of Kampung: Risk and Resilience in The Urban Communities of Surabaya, Indonesia. International Journal of Building Pathology and Adaptation, 36(5), 543-568. Doi: https://doi.org/10.1108/IJBPA-02-20180025

Silas, J. (1988). The Kampungs of Surabaya: Institute of Human Settlements, Agency for Research and Development, Ministry of Public Works \& Japan International Cooperation Agency.

Silas, J., \& Ernawati, R. (2013). Liveability of Settlements by People in the Kampung of Surabaya. Paper presented at the Proceedings of the 19th International CIB World Building Congress: Construction and Society, QUT, Brisbane.

Sistyaningsih, I. N., \& Kisnarini, R. (2017). Kampung Vertikal Kawasan Central Business District di Surabaya. Jurnal Sains Dan Seni Its, 6(2), G109-G112. Doi: https://doi.org/10. 12962/j23373520.v6i2.25805

Southworth, M., \& Ben-Joseph, E. (2013). Streets and the Shaping of Towns and Cities: Island Press.

Tallo, A. J., Pratiwi, Y., \& Astutik, I. (2014). Identifikasi Pola Morfologi Kota (Studi Kasus: Sebagian Kecamatan Klojen, di Kota Malang). Jurnal Perencanaan Wilayah dan Kota, 25(3), 213-227. Doi: https://doi.org/10.5614/jpwk.2015.25.3. 3

Trancik, R. (1991). Finding Lost Space: Theories of Urban Design: John Wiley \& Sons.

Wei, R., Song, D., Wong, N. H., \& Martin, M. (2016). Impact of Urban Morphology Parameters on Microclimate. Procedia Engineering, 169, 142-149. Doi: https://doi.org/10.1016/j.proeng.2016.1 0.017

Whitehand, J., Samuels, I., \& Conzen, M. P. (2009). Conzen, MRG 1960: Alnwick, Northumberland: a Study in Town-Plan Analysis. Institute of British Geographers Publication 27. London: George Philip. Progress in Human Geography, 33(6), 859864. Doi: https://doi.org/10.1177/ 0309132509334948 
Yaguang, S. (2011). Development and Characteristics of Central Business District Under The Philosophy of Health. Procedia Engineering, 21, 258-266. Doi: https://doi.org/10.1016/j.proeng.2011.1 1.2013

Yu, W., Ai, T., \& Shao, S. (2015). The Analysis and Delimitation of Central Business District Using Network Kernel Density Estimation. Journal of Transport Geography, 45, 3247. Doi: 10.1016/j.jtrangeo.2015.04.008

Zahnd, M. (1999). Perancangan Kota Secara Terpadu: Kanisius.

Zia, M. M., \& Rho, J. H. (2014). The Compact City Concept in Creating Resilient City and Transportation Systme in Surabaya. Procedia-Social and Behavioral Sciences, 135, 41-49. Doi: 10.1016/j.sbspro. 2014.07.323

Živković, J. (2019). Urban Form and Function. In W. Leal Filho, U. Azeiteiro, A. M. Azul, L. Brandli, P. G. Özuyar \& T. Wall (Eds.), Climate Action (pp. 1-10). Cham: Springer International Publishing.

Zulfiyah, I. (2017). Masyarakat Miskin Urban di Stren Kali Barata Jaya Surabaya. Paradigma, 5(3), 1-6. 